\title{
Innovative Approaches and Methods in Teaching Technical Subjects
}

\section{${ }^{1}$ K.J. Rustamov, ${ }^{2}$ S.I. Komilov, ${ }^{3}$ Kh.Dj. Djumaev, ${ }^{4}$ M.R.Tadjikhodjayeva, ${ }^{5}$ Sh.Abdukarimova}

\author{
${ }^{12345}$ Tashkent State Transport University, Tashkent City, 100167, Temiryulchilar 1, Uzbekistan, \\ ${ }^{1}$ k.j.rustamov82@gmail.com, ${ }^{2}$ skomilov1974@mail.ru, ${ }^{3}$ djumaev1959@mail.ru, ${ }^{5}$ woxsanam1990@gmail.com
}

Article History: Received: 11 January 2021; Accepted: 27 February 2021; Published online: 5 April 2021

\begin{abstract}
Relevance. In the learning process, it is necessary to pay attention, first of all, to those methods in which listeners identify themselves with the educational material, are included in the studied situation, are encouraged to take active actions, experience a state of success and accordingly motivate their behavior.

Aim. The purpose of our experimental study was to determine the possibility and effectiveness of using active and interactive forms in teaching technical disciplines.

Methods. Scientific methods were applied such as working with documents, comparative analysis, literature review, questionnaires, statistics, etc.

Results. In the results of experimental work, the indicators of students are given for three years in three subjects: theoretical mechanics, practical mechanics and modelling.

Conclusion. In the conclusion, conclusions are given on this topic.
\end{abstract}

Keywords: innovative approach, teaching methods, technical subjects, interactive ways of teaching.

\section{Introduction}

Innovative technologies are those that involve not so much the mastery of the discipline as the formation of competencies, for which they use active and interactive teaching methods. Such technologies include, for example, information and communication technologies (involving computer science in the study of technical disciplines), student-centered technologies (developing natural data of students, communication skills), didactic (using new techniques, methods in the educational process), etc.

From the first meetings with students, teachers of technical disciplines should provide a concrete understanding of the goals of studying the discipline, the contribution of this discipline to the formation of competencies. For this, the educational program should provide for the most part a problematic, research nature of education, motivating future graduates to acquire the required competencies. It is customary to single out several basic methods of organizing classes used by teachers in their field [4]. The passive method is a form of interaction between the teacher and the student, in which the teacher is the main actor who controls the course of the lesson, and the students act as passive listeners. We do not believe that the passive method should be completely abandoned. The question is in the ratio, in the share of passive methods in the entire process of cognition. This method shouldn't take over.

An active teaching method is the organization of the educational process, which promotes a more active than with a passive method, interaction with the teacher. If passive methods presupposed an authoritarian style of interaction, then active ones presuppose a democratic style. At the same time, the teacher "has to revise the traditional teaching methodology, when the classroom has only the usual blackboard and chalk" [41].

Interactive method. Today it is not enough to be competent only in one's own field and be able to transfer a certain amount of knowledge to students. Currently, the teacher needs to organize the process in such a way as to involve the students themselves in obtaining knowledge, which is facilitated by active, and even more interactive teaching methods. It is known that learners can more easily understand and remember the material they have learned through active involvement in the learning process. The interactive method is the "closure" of students to themselves. The main thing is the communication of students with each other in the process of acquiring knowledge. The role of the teacher in interactive classes is reduced to the direction of students' activities to achieve the objectives of the lesson. Interactive learning is primarily interactive learning.

There are many forms of active and interactive learning, let us recall only some of them: creative assignments, lectures with a mistake, brainstorming, conferences with presentation of reports and discussion, educational discussion, teaching using computer programs, case method. The case method can be presented as a complex system, which includes other, simpler methods of cognition. It includes modeling, systems analysis, problem method, thought experiment, simulation, classification methods, game methods that play their roles in the case method [22]. The acquisition of competencies is based on performance. This means that the very possibility of assimilating knowledge, skills, abilities depends on the activity of students. It is the task of the teacher of a higher educational institution to organize this activity correctly. 


\title{
Materials and Methods
}

Literature review. Problems of teaching methods in educational process, self-development, innovative and interactive ways of teaching were studied by representatives of various areas of science in the works of following researchers: in mechanics: T. Askarhodjaev [2], K.Rustamov [2, 32, 33, 15], F. Aymatova [2], G. Husenova [2], in social sciences and IT: L.A.Burnyasheva [4], B. S. Gershunsky [9], V.V.Petrusinskiy [27], E.J.Galimova [7], N.R.Rustamova [15, 34, 35, 36, 37, 45], D.M.Yunusova [45], I.N.Ilhamova [45], K.I.Daulanova [45], E.A.Genike [8], A.M.Gornostaeva [12], J.Kovalevskaya [20], N.I.Kudryashev [21], C.L.Rubinsteyn [31], G.A.Golovin [11], S.S.Kashlev [18, 19],V.A.Slastenin [39],O.B.Voronkova [44], N.N.Rostovcev [30], A.K.Artemov [1], O.I.Davydova [5], N.F.Efremova [6], Dzh.Gilford [10], I.A.Lerner [23], E.A.Savina [38], O. Kulibina [24] and others. Problems interactive ways of teaching in technical subjects were studied by: I.V. Buderetskaya [3], L.T. Raevskaya [28], E.M. Rogova[29], Yu.G. Tatur [41], I.S. Ishbaev [14], A.D. Ivanova [16], Z.S. Kutrunova[22], S.V.Maksimova [22], A.A.Voronov [22], L.V. Tereshina [42] and others.

\begin{abstract}
Aim of research
Long-term observations of the educational process revealed an increasingly weaker mathematical training of applicants, a lack of independence and interest in learning, a desire to look for an answer on the Internet for any reason, inability to concentrate, fear of public speaking and a lack of tolerance for the statements of others. All this stimulated the search for some new approaches to working with current students.

In the learning process, it is necessary to pay attention, first of all, to those methods in which listeners identify themselves with the educational material, are included in the studied situation, are encouraged to take active actions, experience a state of success and accordingly motivate their behavior. For example, a discussion in small groups gives each participant a chance to bring something of their own into the discussion, feel independence from the teacher, show leadership qualities, and repeat the material. And while the new perspectives on learning are not accepted by all teachers as a guide to changing their own teaching patterns, finding interactive ways to interact with the group, research evidence that using active approaches is an effective way of learning cannot be ignored.

The purpose of our experimental study was to determine the possibility and effectiveness of using active and interactive forms in teaching technical disciplines. The research objectives were as follows:

for three years, monitor the results of intermediate certifications in several technical disciplines in a number of groups;

in several groups, gradually from year to year, increase the share of active and interactive approaches both in lectures and in practical and laboratory classes;

conduct traditional classes in technical disciplines in one group;

to carry out a comparative analysis of the results of intermediate certification in groups with a large share of active methods and in the group of traditional education for three years;

gather information as far as possible on the main best practices. Classes in all groups were taught by the same teacher.
\end{abstract}

\section{Methods}

Based on the objectives of the study, the groups of directions "Engineering of technological machines" (undergraduate profile) were selected, with which the authors of this article worked. We used active forms of interaction in teaching such disciplines as "Theoretical Mechanics", "Practical Mechanics", "Modeling". Theoretical mechanics is studied in the third semester, students take an exam and coursework with grades. Practical mechanics is given in the fourth semester, as a result, students should receive credit. The course "Modeling" is taught to bachelors of the third year of study, intermediate certification is a test. Several methods were selected.

The brainstorming method was used mainly in the lecture. Lectures necessarily contained problematic questions, the answer to which was proposed to be found by this method. In theoretical mechanics, for example, it was necessary to determine the number of unknown reactions of supports in statics, to formulate the concept of a vector-moment or the order of solving problems. In the course of technical mechanics, at the first acquaintance with the groups, it was proposed to calculate the class of a given group, to simulate a group of the 4th class, followed by a performance in front of the entire audience, in which it was necessary to justify their choice. In a lecture on the discipline "Modeling", after explaining the classification of types of modeling, it was proposed to characterize the virtual modeling program, which reproduces on a computer the process of flowing around an object with any liquid or gas (which was demonstrated by a slide show). It was necessary to answer the questions: real or mental model, dynamic or static, discrete or continuous, etc.

The creative assignment method helped develop students' research skills. Students received such tasks after getting acquainted with the basic approaches to formalization and modeling of balance and movement of material bodies. For example, in theoretical mechanics in the problems of the "Statics" section, freshmen were 
asked not only to calculate the reactions of connections, but also to find their dependence on the type of connections. After a little research, they should conclude about the benefits of certain supports. In the sections "Kinematics" and "Dynamics", students solve the same problem using different methods, which broadens their horizons, helps to repeat the material and forms problem solving skills. In technical mechanics, it was necessary to carry out a comparative analysis of methods for solving statically indeterminate problems. Beam-bar structures were proposed for consideration, the solution should be carried out by the energy method and the method of comparing deformations and justify the advantages of one method or another.

Case-study method is a proposal to a group of a specific situation in order to find a solution, justification of this decision with a detailed analysis of the search for a solution. It became possible to use the case method in teaching technical disciplines for work in small groups. Activity in small groups is one of the most effective strategies, as it gives all students the opportunity to participate in work, practice cooperation skills, interpersonal communication (in particular, the ability to actively listen, develop a common opinion, resolve differences that arise). For example, freshmen who started to study theoretical mechanics were offered tasks such as "Two loads of masses $\mathrm{m} 1=\mathrm{m} \mathrm{kg}$ and $\mathrm{m} 2=3 \mathrm{~m} \mathrm{~kg}$, connected by a weightless inextensible thread, must be lifted and moved. One worker suggested lifting the load by grabbing the first load, the second worker suggested holding on to the second load when lifting, and the third said that it doesn't matter which weight to hold on to, it would not break the thread between the weights. Who is right? In what situation is less likely to break the thread, if in any case the same force $\mathrm{F}$ is applied to the corresponding load for lifting? " At the beginning of the lesson, the principles of work in a group were discussed: the lesson is not a lecture, general work is supposed with the participation of each student in the group; all participants are equal regardless of age, social status, experience; each participant has the right to their own opinion on any issue; there is no place for direct criticism of the individual (only an idea can be criticized).

The time for discussion of the task and solution was limited to 30-40 minutes. After that, a representative of each group made a short message in accordance with the listing of issues that needed to be covered. The questions included not only the result of the solution, but also the analysis of the process of finding a solution. After the presentation of all groups, the teacher summed up the results, indicating the common mistakes, and made conclusions.

The method "Computer simulation" was used in teaching the discipline "Modeling in engineering". Students, for example, were offered tasks on modeling a technological process using visualization tools. It was proposed to diagnose the transient process when starting the device, and then, by the selection of parameters, to optimize the transient process. The group was divided into subgroups of 2 students. The following goals were set: 1) familiarization with the instrumental applications of the Scilab software package, obtaining the skills of initial work with the Xcos visual modeling system; 2) computer study of the dynamic properties of the object. As an example, the simplest closed-loop system for regulating the liquid level in the flow with negative feedback was proposed, including a control object $(\mathrm{OU})$ in the form of an inertial link of the 1st order with delay and a control device (CU) representing a PI-controller (see Fig. 1 ). The flow level h is regulated by changing the position $\mathrm{S}$ of the adjustable gate.

Students should create a system model from the corresponding blocks in the application palette, investigate the transient process, select such transfer coefficients, integration time constants that would reduce the transient process time and the amplitude of oscillations when starting the level control system. Parameters $\mathrm{kp}$ - the gear ratio of the regulator; $\mathrm{Ti}$ - integration times were tuning. h3 - set flow level. Modeling of the process began with drawing up a differential equation and obtaining the transfer functions of the control object (Wo (p)) and the control device $(\mathrm{Wp}(\mathrm{p}))$. After working in the program according to the obtained schedule of the transient process, it was necessary to make sure that the specified tuning parameters of the controller $\mathrm{kp}$ and $\mathrm{Ti}$ were correct. Choosing the parameters, we optimized the transient process.

Testing method. The department has developed sets of test tasks on computers, containing hundreds of tasks in sections of general technical disciplines. They are offered to students to check the assimilation of the material after passing some sections of technical disciplines during the semester. These tasks require some research and a rather lengthy calculation. In the computer class of the department, testing on certain topics helps to master the educational material.

Thus, such professional competencies as PC-1, PC-2, PC5, PC-6 are formed, which are necessary, for example, for the qualification of bachelors of the direction "Engineering of technological machines".

General cultural competences should also be formed in the study of technical disciplines. The ability is logically correct, reasoned to build oral speech (OK-2), culture of thinking, goal setting, self-development, advanced training (OK-1, OK-6), organizational skills, teamwork. To develop the skills of competent oral speech and overcome the fear of public speaking, for example, in the process of studying the course "Practical Mechanics", each student is invited to prepare an essay and make a presentation on the chosen topic. Students are introduced to the rules for creating slides for a presentation and the timing of the presentation. Here are several topics of reports related to future professional activities in the field of mechanical engineering: 
- methods and means of protection against vehicle vibrations;

- industrial safety;

- vibration and protection against it;

- vibration damping.

\section{Results}

In our universities in Uzbekistan, in the assessment process, a one-hundred-point assessment of the results of intermediate certification is used. Below are some of the results. Average mark in the group for the course work in theoretical mechanics (in groups where the share of active and interactive methods increased annually): 1st year - 73.2 points, 2nd year - 77.4 points, 3rd year - 78, 2 points. Approximately the same dynamics can be traced in the exam grades in practical mechanics. Average score for the test in practical mechanics: 1st year 77.9 points, 2 nd year -80.7 points, 3rd year - 89.4 points. In the group with a predominance of passive teaching aids, the results over the course of three years remained approximately the same: 71-74 points for coursework, 72-76 for practical mechanics. Average score in the group for a test in modeling in technology: 1st year - 69.7 points, 2nd year - 77.6 points, 3rd year - 79.7 points. Figure 1 shows the average results for the last three academic years compared to the 2020-21 academic year (dominated by the passive teaching method) in some technical disciplines.

\section{Scores os students for three years}

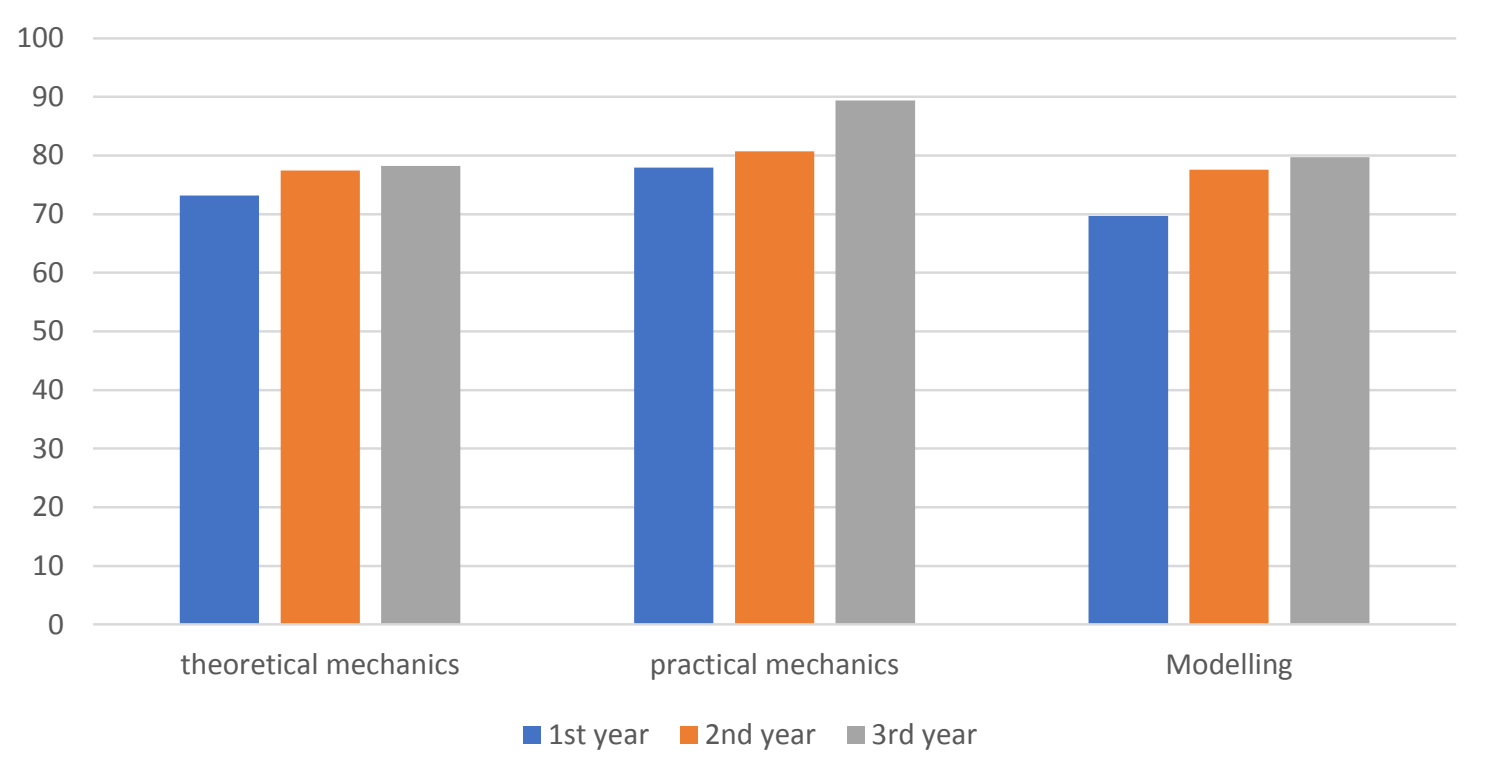

Fig. 1. Row 1 - Theoretical Mechanics, Row 2 - Practical Mechanics, Row 3 -Modelling

\section{CONCLUSION}

Thus, one can state an improvement in learning outcomes in all disciplines, but changes in practical mechanics are especially noticeable, where the average score for 3 years was 82.7 , and in relation to the average value, the increase in the third year was $8.7 \%$. And although the results for other disciplines are more modest, it can be assumed that the use of active and interactive approaches in teaching makes it possible to more effectively approach the fulfillment of the requirements of federal state educational standards. The use of innovative technologies requires significant methodological work from the teacher: preparation of cards, assignments, slides, manuals. All this contributes to a higher level of assimilation of educational material. In addition, this can be achieved by solving non-standard problems, by participating in intra-university, city and regional Olympiads, for example, in theoretical mechanics, in which students of our university actively participate. The main results in the formation of general cultural competencies are as follows: students have become more active in the educational process, have acquired the skill of working in a team. In the future, it is planned to spread the experience of using new teaching methods to such disciplines as "Mechatronics" for masters, "Analytical mechanics", "Strength of materials". 


\section{REFERENCES}

1. Artemov, A.K. Priemyorganizaciirazvivajushhegoobuchenija. Nachal'najashkola. 1995. Issue 3. pp. 3539.

2. Askarhodjaev, T., Rustamov, K., Aymatova, F., \&Husenova, G. (2020). Justification of the hydraulic system parameters of the excavation body of a multi-purpose road construction vehicle based on the TTZ tractor. JournalofCriticalReviews, 7(5), 229-234. doi:10.31838/jcr.07.05.40.

3. BuderetskayaI V.

Interaktivnyemetodyobucheniya.Materialyseminara «Interaktivnyemetodyiinnovatsionnyetekhnologiiobucheniyavobrazovatel'nomprotsesse» [Elektronnyiresurs]. URL: http://nsportal.ru/nachalnaya-shkola/materialy-mo/2013/12/21/interaktivnyemetody-obucheniya.

4. Burnyasheva, L.A. Aktivnyeiinteraktivnyemetodyobuchenijavobrazovatel'nomprocessevysshejshkoly. MetodicheskoeposobieMoscowKnoRus, 2016. p. 219.

5. Davydova, O. I. Interaktivnyemetody v organizaciipedsovetov v DOU. Moscow,Detstvo-Press, 2016. p. 176.

6. Efremova, N.F. Podhody $\mathrm{k}$ ocenivanijukompetencij v vysshemobrazovanii: uchebnoeposobie. Moscow,Issledovatel'skijcentr problem kachestvapodgotovkispecialistov, 2010. p. 216.

7. Galimova, Elena JakovlevnaIspol'zovanieInteraktivnyh Form Obuchenija V IzucheniiKursa «OrganizacionnoeProektirovanie»: Nauch. Doklad - Moskva: Mashinostroenie, 2018. p. 276.

8. Genike, E.A. Aktivnyemetodyobuchenija. Novyjpodhod. Moscow,Nacional'nyjknizhnyjcentr, 2015. p. 832.

9. Gershunskij

B.S.,

Filosofijaobrazovanija: Uchebnoeposobiedljastudentovvysshihisrednihpedagogicheskihuchebnyhzavedenij.

Moscow,Moskovskijpsihologo-social'nyjinstitut, 1998. p. 432.

10. Gilford Dzh. Prirodaumstvennogorazvitijacheloveka. Moscow, Progress, 1967. p. 306.

11. Golovin, JurijAlekseevich; KohanajaOl'gaEvgen'evnaInnovacionnyeMetodyObuchenijaStudentovUniversiteta V Institute Mass Media: MaterialyUchebno-MetodicheskojKonferencii. Moscow, 2008, IL, 2018. p. 625.

12. Gornostaeva, A. M. Dialog s komp'juterom. Interaktivnyesredstvaobuchenija, sozdannyepripomoshhiprogrammy Macromedia Flash (+ CD-ROM). Moscow, Globus, Panorama, 2018. p. 120.

13. Grazhdanskoeobrazovanie. Coderzhanieiaktivnyemetodyobuchenija.

Moscow, Mezhregional'najaassociacija "Za grazhdansokeobrazovanie", Fond "Sivitas", 2013. p. 184.

14. Ishbaev I.S. Problemyprepodavaniyatekhnicheskikhdistsiplin vysshikhuchebnykhzavedeniyakhiosobennostiraboty so studentami. Materialy IX Mezhdunarodnoistudencheskoinauchnoikonferentsii «Studencheskiinauchnyi forum». https://scienceforum.ru/2017/article/2017031725.

15. Isyanov, R., Rustamov, K., Rustamova, N., \&Sharifhodjaeva, H. (2020). Formation of ICT competence of future teachers in the classes of general physics. Journal of Critical Reviews, 7(5), 235-239. doi:10.31838/jcr.07.05.41.

16. Ivanova A.D. Osobennostimetodicheskikhipsikhologo-pedagogicheskikhaspektov $\mathrm{v}$ prepodavanii «Pedagogikiipsikhologiivyssheishkoly»

Sovremennyeproblemynaukiiobrazovaniya. 2015. №6. URL: http://www.scienceeducation.ru/ru/article/view?id=23.

17. Kashlev, S. S. Interaktivnyemetodyobuchenija. Moscow, TetraSistems, 2013. p. 224.

18. Kashlev, SergejSemenovichInteraktivnyemetodyobuchenija. Uchebno-metodicheskoeposobie. Moscow, TetraSistems, 2013. p. 716.

19. Kungurtseva G.F., Ivanova A.D., Shamsutdinova D.F. Kompetentnostnyipodkhod k formirovaniyuprofessional'noikul'turybudushchikhekonomistov.Upravlenieekonomikoi: metody, modeli, tekhnologii: Materialy XV mezhdunarodnoikonferentsii, V 2. Ufa: UGATU, 2015. 212-215 p.

20. Kovalevskaja, JulijaInteraktivnyemetodyobuchenija $\mathrm{v}$ juridicheskomobrazovanii. - M.: LAP Lambert Academic Publishing, 2013. p. 812.

21. Kudryashev, N. I. Vzaimosvjaz' metodovobuchenijanaurokahliteratury. - Moskva: RGGU, 2015. 192 p.

22. Kutrunova Z.S., Maksimova S.V., Voronov A.A. Opytprepodavaniyainzhenernykhdistsiplin s primeneniemelementovpraktiko-orientirovannogopodkhoda «Conceive - Design - Implement Operate». Internet-zhurnal «Mir nauki» 2017, Tomsk.

23. Lerner I.Ja. Didakticheskieosnovymetodovobuchenija. Moscow, Pedagogika, 1981. p. 185.

24. KulibinaOl'gaValer'evnaAktivnyemetodyobuchenija: gigienaijekologija v medicinskomvuze. Moscow, LAP Lambert Academic Publishing, 2014. p. 925.

25. Ivanova A.D.Osobennostimetodicheskikhipsikhologo-pedagogicheskikhaspektov v prepodavaniimatematikinagumanitarnykhspetsial'nostyakh $\mathrm{v}$ tekhnicheskikhvuzakh. Teoretikometodologicheskieproblemyestestvennonauchnykhmetodov gumanitarnykhnaukakh: 
Materialymezhdunarodnoinauchno-prakticheskoikonferentsii. Ufa, «AETERNA», 2014. pp.472-481

26. Pavlenko, B.M. Zolotyehity pod gitaru. Beznotnyjmetodobuchenija. Moscow, Feniks, 2014. p. 135.

27. Petrusinskij, V. V. Igrydljaaktivnogootdyha v processeobuchenija. Moskva: Vysshajashkola, 2014. p. 128.

28. Raevskaya L.T. Professional'nyekompetentsiipriizucheniiteoreticheskoimekhaniki. Obrazovanieinauka: sovremennoesostoyanieiperspektivyrazvitiya: sborniknauchnykhtrudov

po materialamMezhdunarodnoinauchno-prakticheskoikonferentsii 31 iyulya 2014 g.: v 6 ch. Ch. 1. Tambov: OOO «KonsaltingovayakompaniyaYukom», 2014. pp. 143-144.

29. Rogova E.M. Osobennostiorganizatsiiprotsessaobucheniyanaosnovekeis-metoda. Metodicheskoeposobie. Sovremennyetekhnologiiobucheniya v vuze. Otdeloperativnoipoligrafii NIU VShE. Sankt-Peterburg, 2011. 134 p.

30. Rostovcev, N. N. Istorijametodovobuchenijarisovaniju. Moscow,Prosveshhenie, 2016. p. 240.

31. Rubinshtejn C.L. O myshleniiiputjah ego issledovanija. Moscow, AISSSR institutfilosofii, 1958. p. 146.

32. Rustamov K.J. (2019). Experimental Work of the Hydraulic Equipment of the Multi-Purpose Machine Mm-1. (International Journal of Recent Technology and Engineering Volume-8) Issue-4, November 2019. pp. 12032- 12036

33. Rustamov, K. J. (2020). Technical solutions and experiment to create a multipurpose machine. International Journal of Scientific and Technology Research, 9(3), 2007-2013. Retrieved from www.scopus.com

34. Rustamova N. R., (2019). Using of vitagenic technology in the education system. ProceedingofThe ICECRS, 3. https://doi.org/10.21070/icecrs.v3i0.356.

35. Rustamova N.R., The Technology of Developing Media Culture in Secondary School Students. International Journal of Innovative Technology and Exploring Engineering (IJITEE), ISSN: 2278-3075, Volume-IX, Issue-II, December 2019. Aviable to: https://www.ijitee.org/wpcontent/uploads/papers/v9i2/B6181129219.pdf

36. Rustamova, N. R. (2020). Development of technology based on vitagenic experience using media resources in higher educational institutions students teaching. International Journal of Scientific and Technology Research, 9(4), 2258-2262. Retrieved from www.scopus.com

37. Rustamova, N. R. (2020). Training of students of cognitive processes based on vitagen educational situations. International Journal of Advanced Science and Technology, 29(8 Special Issue), 869-872. Retrieved from www.scopus.com

$\begin{array}{lllll}\text { 38. Savina, } & \text { E. Aktivnyeiinteraktivnyemetodyitehnologiiobuchenija } & \mathrm{v}\end{array}$ podgotovkespecialistovinvesticionno-stroitel'nojsfery sistemedopolnitel'nogoprofessional'nogoobrazovanija. Moscow,MGSU, 2015. p. 120.

39. Slastenin V.A. Osnovnyetendenciimodernizaciivysshegoobrazovanija. Pedagogicheskoeobrazovanieinauka No.1, 2004. pp.43-49.

40. Tat'jana, Vetoshkina und Natal'jaShnajderAktivnyeiinteraktivnyemetodyobuchenija. Moscow,LAP Lambert Academic Publishing, 2015. - p. 164.

41. TaturYu.G. Obrazovatel'nyiprotsess v vuze: metodologiyaiopytproektirovaniya: ucheb. Posobie.Moscow, Izd-vo MGTU im. N.E. Baumana, 2009. - 262 p.

42. Tereshina, L. V. Dejatel'nostnyjmetodobuchenija. Opisanietehnologii, konspektyurokov. 1-4 klassy. Moscow,Uchitel', 2014. p. 120.

43. Vigotskij L.S. Pedagogicheskajapsihologija.Moscow, Pedagogika, 1991. p.480

44. Voronkova, O.B. Informacionnyetehnologii v obrazovanii. Interaktivnyemetody. Moscow,Feniks, 2018. p. 598.

45. Yunusova, D. M., Ilhamova, I. N., Daulanova, K. I., Rustamova, N. R., \&Normuradova, G. M. (2020). Using of interactive educational technologies in teaching medical terms. Journal of Advanced Research in Dynamical and Control Systems, 12(6 Special Issue), 596-601. doi:10.5373/JARDCS/V12SP6/SP20201068 